\title{
Light, temperature, nauplii concentrations, and prey capture by first feeding pollock larvae Theragra chalcogramma
}

\author{
A. J. Paul \\ Institute of Marine Science, Seward Marine Center, University of Alaska, Seward, Alaska 99664, USA
}

\begin{abstract}
Digestion rate of first feeding larvae of pollock Theragra chalcogramma fed copepod nauplii averaged $5.0 \mathrm{~h}$. Threshold light levels at which larvae captured prey were between 0.2 and 0.4 lux. Larvae reared and fed at $5.5^{\circ} \mathrm{C}$ were more successful at capturing nauplii than cohorts reared and fed at $3.0^{\circ} \mathrm{C}$ when feeding at low prey concentrations. Yolk sac larvae feeding on wild copepod nauplii at concentrations of $50,14,12,10$, and $8 \mathrm{I}^{-1}$ were similarly successful at capturing prey with averages of $10 \%$ to $14 \%$ of them feeding. At nauplii concentrations of 6 and $2 l^{-1}, 5 \%$ and $2 \%$ of the larvae captured prey, respectively. In all feeding and prey concentration observations, there was a wide range in the percentage of larvae with prey. The results suggest that some larvae can successfully initiate feeding at prey concentrations previously observed in the southeastern Bering Sea.
\end{abstract}

\section{INTRODUCTION}

The Alaska pollock Theragra chalcogramma constitutes 20 to $50 \%$ of total fish community biomass in the southeastern Bering Sea (Pereyra et al., 1976). Currently, little information concerning larval feeding behavior of this commercially important species is available. Light (Ellertsen et al., 1980), temperature (Laurence, 1978) and prey concentration (Hunter, 1976; Houde and Schekter, 1978) have been identified as factors affecting feeding success of larval fish. The objective of this study was to examine the effects of these 3 parameters on prey capture by first feeding pollock larvae. Limited observations on digestion rates were also made. These observations contribute to interpretation of larval feeding in the sea and suggest in situ experiments.

In the southeastern Bering Sea, pollock eggs generally hatch at temperatures of $3^{\circ}$ to $6^{\circ} \mathrm{C}$, and first feeding larvae, 4 to $5 \mathrm{~mm}$ long, are commonly found at depths between 10 and $30 \mathrm{~m}$ (Haryu, 1980; T. Nishiyama, Univ. of Alaska, pers. comm.). Copepod nauplii, ca. 100 to $300 \mu \mathrm{m}$ in length, have been identified as the primary prey of first feeding pollock (Kamba, 1977; Clarke, 1978). Southeastern Bering Sea nauplii concentrations generally range from 0 to $351^{-1}$ where the larvae are encountered (M. E. Clarke, Scripps Inst. of
Oceanog., pers. comm.). The values for experimental parameters examined were selected to simulate the above in situ conditions.

\section{MATERIALS AND METHODS}

Pollock were caught by hook and line and held several months in large indoor pools where they spawned and eggs were fertilized. Floating eggs collected daily from tank overflow traps were incubated in $500 \mathrm{ml}$ containers at either 3.0 or $5.5^{\circ} \mathrm{C}$. Light levels in incubator chambers were $12 \mathrm{~h}$ each of $3 \mathrm{lux}$ and darkness. Dead eggs were removed daily and $100 \mathrm{ml}$ of freshly filtered sea water was replaced in each container. Newly hatched larvae were separated from eggs daily and each hatch treated as a separate experimental group. Rotifers Brachionus plicatilis, fed Tetraselmis suesica and Isochrysis galbana, were introduced into all containers with newly hatched larvae at concentrations of 1 prey $\mathrm{ml}^{-1}$. Pollock larvae thus had an opportunity to interact with food particles in their environment prior to feeding. Feeding studies were initiated when at least $10 \%$ of the larvae had rotifers in their stomachs. Following hatching, the age at which $10 \%$ of the larvae began to feed ranged from 16 to $18 \mathrm{~d}$ and 5 to $9 \mathrm{~d}$ for larvae reared at 3.0 and $5.5^{\circ} \mathrm{C}$, 
respectively. Only larvae that had yolk remaining were utilized for feeding observations. Pollock larvae utilized in these observations had an average total length of $4.7 \pm 0.4 \mathrm{~mm}$ and $7 \pm 1 \times 10^{-5} \mathrm{~g}$ dry weight. Brachionus plicatilis or Tigriopus californicus nauplii, passed through a $300 \mu \mathrm{m}$ but retained by a $100 \mu \mathrm{m}$ screen, were utilized as food in experiments where the variables were light levels or temperature and a 'standard' prey type was required. Wild copepod nauplii, similarly screened, were utilized to simulate natural food in gut clearance and prey concentration feeding success observations.

To examine effects of light levels on feeding activity, larvae were pipetted into transparent $60 \mathrm{ml}$ containers containing Brachionus plicatilis at concentrations of either $20 \mathrm{ml}^{-1}, 10 \mathrm{ml}^{-1}$, or $2 \mathrm{ml}^{-1}$. The larvae, held at $5.5^{\circ} \mathrm{C}$, were first subjected to a $12 \mathrm{~h}$ dark period, then allowed to feed for $8 \mathrm{~h}$ at light levels of $0.2,0.4,0.7,1.0$, $3.0,6.0,44.0$ and 3000.0 lux. Larvae were examined under a microscope for the presence of prey in the stomachs

To examine effects of temperature on feeding, experiments were conducted by placing groups of 4 larvae in $250 \mathrm{ml}$ translucent plastic bottles filled with $1 \mu \mathrm{m}$ filtered sea water and either $3,6,12,25$, or 100 nauplii. These prey concentrations correspond to $12,24,48$, 100 , and 400 prey $1^{-1}$. Newly hatched Tigriopus californicus, average total body length $130 \mu \mathrm{m}$, were the prey species. The $250 \mathrm{ml}$ bottles, placed in a $24 \mathrm{~cm}$ diameter clear plastic cylinder, were rotated at $1 \mathrm{rpm}$ for $24 \mathrm{~h}$ in the temperature control chambers at 3.0 or $5.5^{\circ} \mathrm{C}$. The light regime was $12 \mathrm{~h}$ each of darkness, then 3 lux. After the light period, larvae were placed into a depression slide and their digestive tracts were examined at $750 \times$ for nauplii. A 2 -factor analysis of variance and multiple linear regression (Snedecor, 1956) were utilized to examine the relationships of water temperature $\left(3.0\right.$ and $\left.5.5^{\circ} \mathrm{C}\right)$, prey concentration $\left(12,24,48,100\right.$ and 400 nauplii $\left.1^{-1}\right)$, and $\arcsin \sqrt{\%}$ of larvae feeding.

Digestive tract clearance rates of wild copepod nauplii were estimated after allowing larvae to feed for $4 \mathrm{~h}$ at $5.5^{\circ} \mathrm{C}$ at 300 lux. Twenty larvae with freshly ingested nauplii were transferred to vials containing Brachionus plicatilis, $20 \mathrm{ml}^{-1}$, and evacuation of digestive tract under active feeding conditions observed. The time required for passage of nauplii through the digestive tract at $5.5^{\circ} \mathrm{C}$ was calculated from hourly observations of larvae under a microscope.

The effect of prey concentration on feeding success was examined utilizing copepod nauplii collected in Resurrection Bay, Alaska, which were passed through 300 and $100 \mu \mathrm{m}$ screens. Copepod nauplii trapped in the $100 \mu \mathrm{m}$ screen were resuspended in filtered water, and with the aid of a microscope, active individuals were pipetted into $1 \mathrm{l}$ plastic bottles containing filtered sea water and 8 pollock larvae. The prey concentration in tests were $2,4,6,8,10,12,14$, and 50 nauplii $1^{-1}$. The 11 bottles, attached along the rim of a $55 \mathrm{~cm}$ wheel, were rotated at $1 \mathrm{rpm}$ for $12 \mathrm{~h}$ in a temperature control room at $5.5^{\circ} \mathrm{C}, 3$ lux. Data are presented as the arithmetic mean and the arcsin $\sqrt{\%}$ of larvae with nauplii in their guts.

\section{RESULTS}

A mean ( $\pm 1 \mathrm{sd}$ ) of $5.0 \pm 0.5 \mathrm{~h}$, range 4.5 to $6.5 \mathrm{~h}$, was required for the first feeding larvae to evacuate nauplii from their digestive tract. Similar evacuation rates were observed for larvae with either 1 or 2 prey in their stomachs.

The light level at which $10 \%$ or more of the pollock larvae successfully captured prey was between 0.2 and 0.4 lux. Light ceased to be a factor limiting prey capture at 0.7 lux and active feeding occurred up to the maximum light level examined, 3000 lux (Fig. 1).

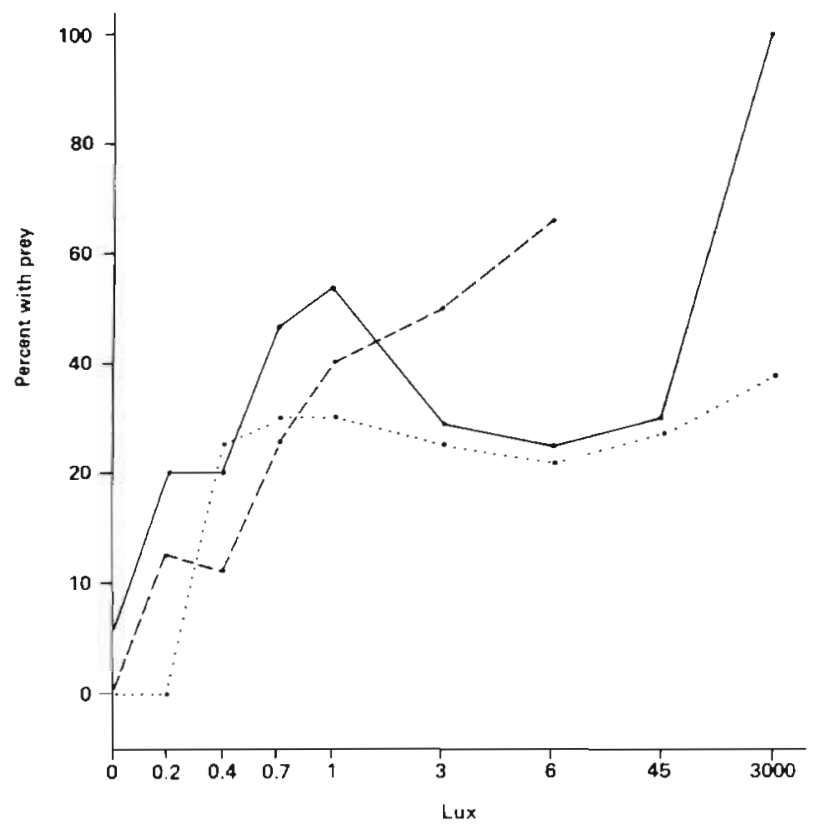

Fig. 1. Percentage of larval Theragra chalcogramma with Brachionus plicatilis in their stomachs relative to light values (0 to 3,000 Iux) and rotifer concentrations ( 20 ind. $\mathrm{ml}^{-1}$ solid line; $10 \mathrm{ml}^{-1}$ dashed line; $2 \mathrm{ml}^{-1}$ dotted line) during feeding

Water temperature had a marked effect on the percentage of pollock larvae capturing Tigriopus californicus nauplii. At $3.0^{\circ} \mathrm{C}$ only $14 \%$ of the larvae feeding at 400 nauplii $1^{-1}$ succeeded in capturing prey, while at $5.5^{\circ} \mathrm{C}$, a similar percentage of larvae fed at prey concentrations of just 24 per liter (Table 1). The Fstatistic, derived from two-way analysis of variance, 
Table 1. Percentage of first feeding Theragra chalcogramma capturing Tigriopus californicus nauplii at 3 and $5.5^{\circ} \mathrm{C}$

\begin{tabular}{|c|c|c|c|c|c|}
\hline $\begin{array}{c}\text { Temperature } \\
\left({ }^{\circ} \mathrm{C}\right)\end{array}$ & $\begin{array}{l}\text { Nauplii } \\
\text { concentrations } \\
\text { (ind. } \mathrm{l}^{-1} \text { ) }\end{array}$ & $\begin{array}{l}\% \text { Larvae } \\
\text { with prey } \\
\text { Mean (sd) }\end{array}$ & $\begin{array}{l}\text { Arcsin } \\
\text { value } \\
\% \text { feeding }\end{array}$ & $\begin{array}{l}\text { Mean no. nauplii } \\
\text { in stomachs of } \\
\text { feeding larvae }\end{array}$ & $\begin{array}{l}\text { No. groups } \\
\text { larvae }\end{array}$ \\
\hline \multirow[t]{5}{*}{5.5} & 400 & 51 (32) & 46 & 1.8 & 11 \\
\hline & 100 & 31 (26) & 34 & 1.2 & 16 \\
\hline & 48 & $17(20)$ & 24 & 1.0 & 20 \\
\hline & 24 & $15(18)$ & 23 & 1.2 & 20 \\
\hline & 12 & 11 (14) & 19 & 1.1 & 20 \\
\hline \multirow[t]{5}{*}{3.0} & 400 & 14 (12) & 22 & 1.0 & 10 \\
\hline & 100 & $13(26)$ & 21 & 1.1 & 16 \\
\hline & 48 & $13(25)$ & 21 & 1.0 & 20 \\
\hline & 24 & $5(10)$ & 13 & 1.0 & 20 \\
\hline & 12 & $6(14)$ & 14 & 1.0 & 20 \\
\hline
\end{tabular}

indicated a significant difference $(95 \%)$ between the 2 temperature groups for arcsin $\sqrt{\%}$ of larvae with prey in their guts, but no significant difference $(95 \%)$ related to nauplii concentration and the same parameter. The model for the multiple linear regression of temperature ${ }^{\circ} \mathrm{C}(\mathrm{T})$, nauplii concentration (N) and arc$\sin \sqrt{\%}$ of larvae feeding (P) was determined to be $\mathrm{P}=0.48+4.38(\mathrm{~T})+0.04(\mathrm{~N}), \mathrm{R}^{2}=0.75$. Thus, water temperature appears to be relatively important in determining the percent of larvae that initiate feeding.

Larvae feeding on Resurrection Bay nauplii at prey concentrations of $50,14,12,10$ and $8 \mathrm{l}^{-1}$ exhibited similar rates of success with arithmetic values of 10 to $14 \%$ of them having prey in their digestive tracts. At prey concentrations of 2 to $6 \mathrm{I}^{-1}$, the percent of larvae capturing prey averaged of 2 to $5 \%$. The arithmetic percentage of feeding larvae exhibited wide ranges with low values of $0 \%$ and high values of $75 \%, 40 \%$, $20 \%, 28 \%$, and $20 \%$ at prey concentrations of $10,8,6$, 4 , and $21^{-1}$, respectively, (Table 2). Arcsin transformation for proportions of feeding larvae suggests that after some equalization of variance, an average of 8 to $18 \%$ of the larvae feeding at 2 to 10 nauplii $1^{-1}$ are predicted to be successful at capturing prey (Table 2).

The average number of Resurrection Bay nauplii in stomachs of feeding larvae ranged from 1 to 1.7 with the higher value observed at prey concentrations above $81^{-1}$. Likewise, larvae consuming 3 or 4 nauplii were restricted to chambers where initial prey counts exceeded $81^{-1}$ (Table 2).

\section{DISCUSSION}

The evacuation rate of $5 \mathrm{~h}$ for first feeding pollock larvae is similar to that of larvae of Atlantic cod Gadus morhua which are able to digest nauplii within $5 \mathrm{~h}$
(Ellertsen et al., 1980). Additional observations on the effect of water temperature, light and prey consumption on the residence time of prey in the digestive tract (Laurence, 1971) are necessary before a better understanding of digestion rate can be obtained.

The light intensity threshold for feeding delimits the length of the daily feeding period. In the southeastern Bering Sea, at depths of 10 to $30 \mathrm{~m}$, light intensities at which pollock can feed, 0.4 lux, are available to the larvae for 12 to $14 \mathrm{~h}$ a day early in the hatching period (J. Goering, Univ. of Alaska, pers. comm.). Observations on feeding Gadus morhua larvae, another gadoid larva that is a visual nauplii predator, demonstrated a threshold requirement of 0.1 to 0.4 lux (Ellertsen et al., 1980), similar to that observed for pollock larvae.

In laboratory conditions, where food is not limiting, the highest survival rates of pollock larvae have been observed at $2{ }^{\circ} \mathrm{C}$ (Hamai et. al. 1971). The present study of larvae feeding at low prey concentrations suggests that individuals hatching early in a season at $3^{\circ} \mathrm{C}$ may be less successful at capturing prey than later larvae hatching at 5 or $6{ }^{\circ} \mathrm{C}$. Conversely, individuals hatching at $5{ }^{\circ} \mathrm{C}$ require $8 \%$ more calories than larvae at $3^{\circ} \mathrm{C}$ (Fukuchi, 1976). Examination of in situ survival rates, both early and late in the hatching season, would aid in determining if survival of pollock larvae is modified by the thermal regime.

Oxygen consumption rates of late yolk sac pollock have been estimated at 3.1 and $3.3 \mu$ larvae la $^{-1}$ at $3^{\circ}$ and $5{ }^{\circ} \mathrm{C}$ respectively (Fukuchi, 1976). Thus, if these larvae require 4.7 calories for each $\mu \mathrm{O}_{2}$ consumed (Crisp, 1971) for respiratory metabolism, and are assumed to be $60 \%$ efficient at converting prey to energy, they require ca. 0.020 to 0.022 calories $\mathrm{d}^{-1}$. A single $2.0 \mu \mathrm{g}$ nauplius would provide ca. 0.01 calories (Houde, 1978). The stomachs of 4 to $5 \mathrm{~mm}$ pollock larvae captured in the southeastern Bering Sea fre- 
Table 2. Percentage of larvae feeding and number of Resurrection Bay copepod nauplii consumed by first feeding Theragra chalcogramma at different prey concentrations in the laboratory. Data: $\bar{x}=$ mean, $\mathrm{sd}=$ standard deviation, $\mathrm{r}=$ range and $\mathrm{C}=$ coefficient of variation

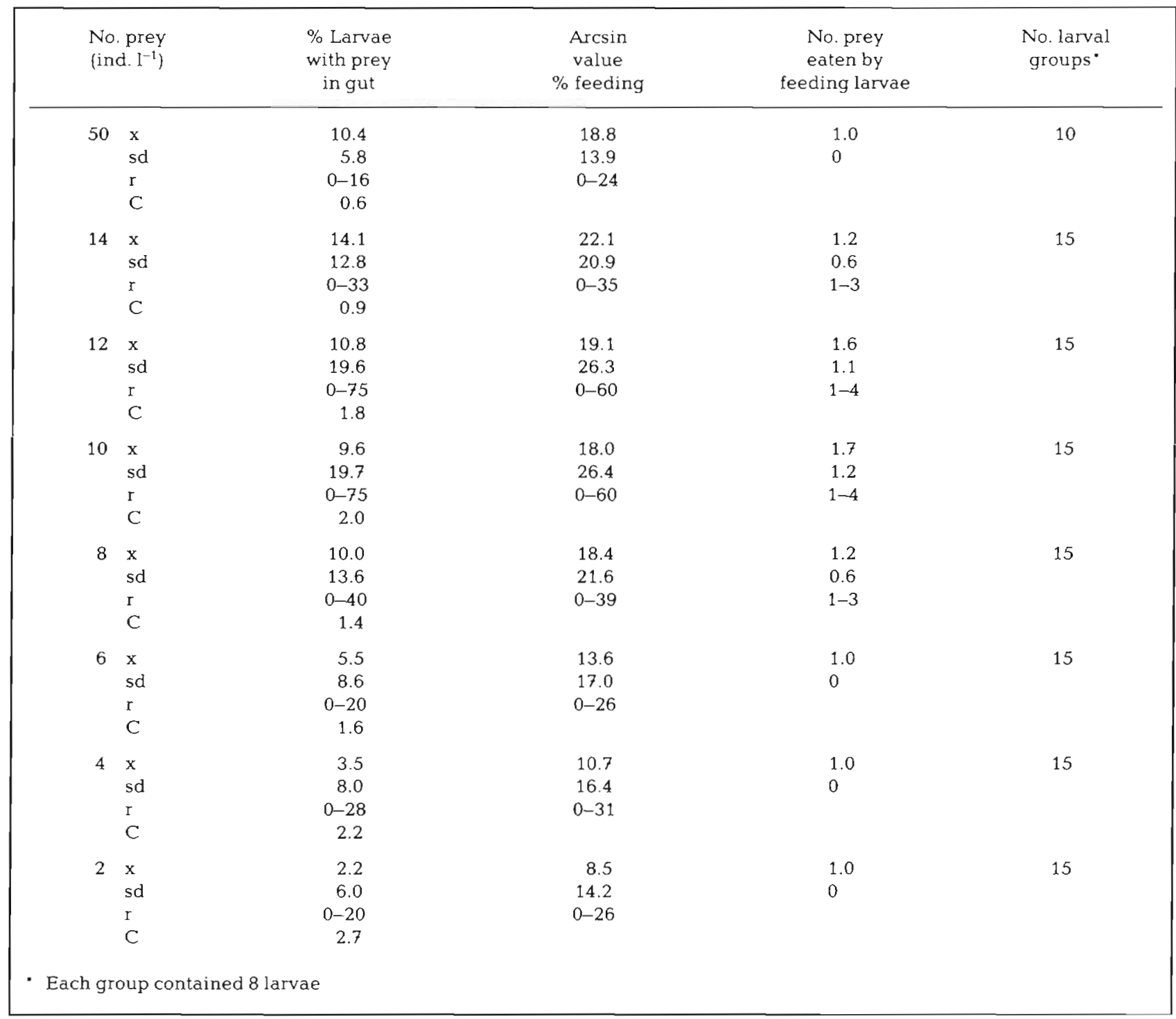

quently contained 3 or 4 nauplii (Clarke, 1978). Successful yolk sac larvae in the laboratory can capture 1 to 4 nauplii $\mathrm{d}^{-1}$ at prey concentrations between 2 and $81^{-1}$ (Table 2). Relatively few larvae were successful at capturing more than 1 nauplius in the laboratory; however, these few competent feeders may be an important aspect of year class survival. Some yolk sac Gadus morhua, like pollock, are able to capture 3 nauplii daily when feeding at prey concentrations on the order of $101^{-1}$ (Ellertsen et al., in press).

Laboratory studies have demonstrated that some larval fish species require higher prey concentrations than those typically observed in the sea to feed successfully (Theilacker and Dorsey, 1980). In contrast, other species have been reported to feed successfully at prey concentrations observed in nature (Houde, 1974,1978 ). At 10 prey $1^{-1}, 35 \%$ of sea bream and $60 \%$ of lined sole larvae, 2 warm-water species, captured prey (Houde and Schekter, 1980). In this study, 10 to $75 \%$ of the yolk sac pollock larvae successfully captured nauplii at prey concentrations observed in nature, 8 to $14 \mathrm{I}^{-1}$. However, because the objective was to work solely with first feeding individuals, the experimental design allowed some larvae that probably were not ready to initiate feeding to be included in the experiments. Furthermore, the non-feeding larvae still had yolk energy and could possibly initiate feeding at a later time. It must also be noted that at prey concentrations of less than $8 \mathrm{l}^{-1}$, there were not enough nauplii for $100 \%$ of the larvae to feed success- 
fully. Thus, it is probable that the mean values for the percentage of larvae feeding on Resurrection Bay nauplii (Table 2) conservatively describes their feeding success at a given prey concentration. Laboratory or in situ observations of feeding rates are now required to verify that larvae can survive at these prey concentrations.

Acknowledegements. This study was supported by the National Science Foundation Division of Polar Programs through the Processes and Resources of the Bering Sea Shelf Program, Grant No. 7623340 to Drs. R. Lasker and H. Feder and University of Alaska, Institute of Marine Science. Facilities were provided by the Institute of Marine Science, Seward Marine Center. J. M. Paul provided laboratory assistance, and M. E. Clarke aided in, experimental design and reviewed the manuscript. J. C. Hendee provided and maintained the spawning pollock. This paper is a contribution, No. 522, from the Institute of Marine Science, University of Alaska.

\section{LITERATURE CITED}

Clarke, M. E. (1978). Some aspects of the feeding biology of larval pollock. Theragra chalcogramma (Pallas), in the southeastern Bering Sea. M. S. Thesis, Univ. of Alaska, Fairbanks, USA

Crisp, D. (1971). Energy flow measurements. In: Holme, N., McIntyre, A. (eds.) Methods for the study of marine benthos, International Biological Program Handbook No. 16. Blackwell Scientific Publications, Oxford, p. 197-279

Ellertsen, B., Solemdal, P., Stromme, T., Tilseth, S., Westgard, T. (1980). Some biological aspects of cod larvae (Gadis morhua L.). FiskDir. Skr. (Ser. Havunders.) 17: 29-47

Ellertsen, B., Solemdal, P., Sundby, S., Tileth, S., Westgard, $T$., Oiestad, V. (in press). Feeding and vertical distribution of cod larvae in relation to availability of prey organisms. FiskDir. Skr. (Ser. Havunders.) 17: in press

Fukuchi, M. (1976). Some aspects of bioenergetics of walleye pollock Theragra chalcogramma (Pallas) at early life stages. Ph. D. thesis, Univ, of Hokkaido, Hokkaido, Japan

Hamai, I., Kyushin, K., Kinoshita, T. (1971). Effects of temperature on the body form and mortality in the developmental and early larval stages of the Alaska pollock, Theragra chalcogramma (Pallas). Bull. Fac. Fìsh. Hokkaido Univ. 22: $11-29$

Haryu, T. (1980). Larval distribution of walleye pollock, Theragra chalcogramma (Pallas), in the Bering Sea, with special reference to morphological changes. Bull. Fac Fish. Hokkaido Univ. 31: 121-136

Houde, E. D. (1974). Effects of temperature and delayed feeding on growth and survival of larvae of three species of subtropical marine fishes. Mar. Biol. 26: 271-285

Houde, E. D. (1978). Critical food concentrations for larvae of three species of subtropical marine fishes. Bull. mar. Sci. 28: $395-411$

Houde, E. D., Schekter, R. C. (1978). Simulated food patches and survival of larval bay anchovy, Anchoa mitchilli, and sea bream, Archosargus rhomoidalis. Fish. Bull. Fish Wildl. Serv. U.S. 76: 483-486

Houde, E. D., Schekter, R. C. (1980). Feeding by marine fish larvae: developmental and functional responses. Environ. Biol. Fish. 5: 315-334

Hunter, J. R. (1976). Culture and growth of northern anchovy Engraulis mordax, larvae. Fish. Bull. Fish Wildl. Serv. U.S. 74:81-88

Kamba, M. (1977). Feeding habits and vertical distribution of walleye pollock, Theragra chalcogramma (Pallas), in early life stage in Uchiura Bay. Res. Inst. N. Pac. Fish., Hokkaido Univ., Spec. Vol.: 175-197

Laurence, G. C. (1971). Digestion rate of larval largemouth bass. N. Y. Fish Game J. 18: 52-56

Laurence, G. C. (1978). Comparative growth, respiration, and delayed feeding abilities of larval cod Gadus morhua and haddock Melanogrammus aeglefinus as influenced by temperature during laboratory studies. Mar. Biol. 50: 1-7

Pereyra, W., Reeves, J., Bakkala, R. (1976). Demersal fish and shellfish resources of the eastern Bering Sea in the baseline year 1975. U. S. Natl. Mar. Fish. Serv., Northwest and Alaska Fish. Cent., Seattle, Wa., Processed Report

Snedecor, G. W. (1956). Statistical methods applied to experiments in agriculture and biology (5th ed.). Iowa State Coll. Press, Ames

Theilacker, G., Dorsey, K. (1980). Larval fish diversity, a summary of laboratory and field research. In: Workshop on the effects of environmental variation on the survival of larval pelagic fishes. UNESCO, Intergovernmental Oceanographic Commission, Workshop Report 28: $105-142$ 